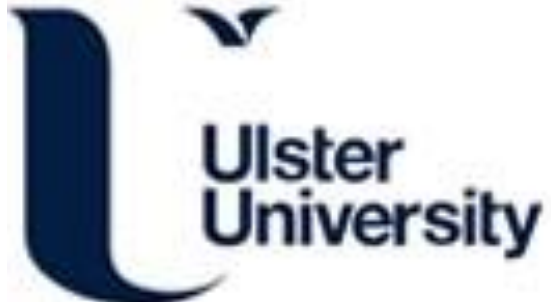

\section{Language skills and employment status of adult migrants in Europe}

Gazzola, M. (2017). Language skills and employment status of adult migrants in Europe. In J-C. Beacco (Ed.), The linguistic integration of adult migrants. Some lessons from research (pp. 297-302). De Gruyter.

Link to publication record in Ulster University Research Portal

\section{Published in:}

The linguistic integration of adult migrants. Some lessons from research

Publication Status:

Published (in print/issue): 12/09/2017

\section{Document Version}

Publisher's PDF, also known as Version of record

\section{General rights}

Copyright for the publications made accessible via Ulster University's Research Portal is retained by the author(s) and / or other copyright owners and it is a condition of accessing these publications that users recognise and abide by the legal requirements associated with these rights.

\section{Take down policy}

The Research Portal is Ulster University's institutional repository that provides access to Ulster's research outputs. Every effort has been made to ensure that content in the Research Portal does not infringe any person's rights, or applicable UK laws. If you discover content in the Research Portal that you believe breaches copyright or violates any law, please contact pure-support@ulster.ac.uk. 


\title{
Language skills and employment status of adult migrants in Europe
}

\begin{abstract}
Using official data from Eurostat, this article examines the relationship between adult migrants' language skills and their integration in the European labour market. We use migrants' employment status as an indicator for integration. Results reveal that migrants who have good or very good skills in the official language of the host country are more likely to have better employment status than those with limited or no language skills. EU migrants tend to be better integrated than non-EU migrants.
\end{abstract}

Résumé : L'article s’appuie sur les données officielles d'Eurostat pour examiner la corrélation entre les compétences langagières des migrants adultes et leur intégration dans le marché européen de l'emploi. La situation des migrants en termes d'emploi sert d'indicateur de l'intégration. Les résultats montrent que les migrants qui ont de bonnes ou de très bonnes connaissances de la langue officielle du pays d'accueil ont des chances de décrocher un meilleur emploi que ceux qui ont des compétences langagières limitées ou nulles. Les migrants issus de l'Union européenne ont tendance à mieux s'intégrer que ceux de pays tiers.

\section{Introduction ${ }^{1}$}

In recent years, the question of migrants' language skills has become a topical issue in Europe. Language skills are viewed as a condition for migrants to be socially and economically integrated in the host country, and as a factor contributing to the international mobility of EU citizens. For example, in many countries, non-EU citizens are required to show adequate language skills in the official lan-

1 The financial support of the EU $7^{\text {th }}$ Framework Programme (MIME project - grant agreement 613344 ) is gratefully acknowledged. The goal of the MIME project ("Mobility and Inclusion in a Multilingual Europe”, 2014-2018) is to discuss the relationships between international mobility, inclusion and language skills in Europe (http://www.mime-project.org); see Grin et al. (2014).

Michele Gazzola, Research Group Economics and Language (REAL), Department of Education Studies, Humboldt-Universität zu Berlin, Germany/Institute for Ethnic Studies, Ljubljana, Slovenia, E-mail: michele@michelegazzola.com

DOI 10.1515/9783110477498-040, (cc) BY-NC-ND (c) 2017 Michele Gazzola, published by De Gruyter. This work is licensed under the Creative Commons Attribution-NonCommercial-NoDerivs 3.0 License. 
guage of the host country in order to obtain a residence permit or citizenship (see Pulinx, Van Avermaet, and Extramiana 2014). In the communication A New Strategic Framework for Multilingualism the European Commission (2005) presents skills in foreign languages as a pre-condition for the achievement of the common market. Empirical evidence tends to support this view. People who learn and speak the official language of a country as a foreign language are five times more likely to move to that country (Aparicio-Fenoll and Kuehn 2016). In addition, proficiency in the official language of the host country has a positive effect on migrants' labour income in a range of 5\% to 35\% (for an overview, see Adserà and Pytliková 2016; Gazzola, Grin, and Wickström 2016; Chiswick and Miller 2014). Drawing on official data published by Eurostat, this article addresses the question of the relationship between adult migrants' language skills and their social and economic integration in the host country. We use migrants' employment status as a proxy indicator for integration.

\section{The language skills of adult migrants}

We use data from the Adult Education Survey (AES) published by Eurostat in 2013. Our initial sample consists of 179,617 statistical observations (corresponding to 240.8 million people), of whom 8,431 are migrants (corresponding to 15.7 million people). We examine 26 European states, that is, the 28 Member States of the EU, excluding Croatia and the UK because of a lack of data. All definitions apply to residents of the EU aged 25-64 (base year 2011). The sample is divided into three groups: EU citizens living in their home country or "nationals" (93\%); EU citizens living in another member state or "EU migrants" (3\%); and non-EU migrants (4\%). Migrants tend to be long-term residents in the host country: $45 \%$ of EU migrants and non-EU migrants alike have been living in the host country for more than 10 years; $23 \%$ of EU migrants and 26\% of non-EU migrants for six to ten years. Only $5 \%$ of EU migrants and $2 \%$ of non-EU migrants have been living for only one year or less in the host country at the time of the survey.

Non-EU migrants are more likely to belong to the first deciles of the income distribution than nationals. This means that, in general, their income is lower than nationals'. On the other hand, differences between EU migrants and nationals in this respect tend to be small. Similarly, differences between nationals and EU migrants as regards the level of education they have successfully completed are not large, whereas non-EU migrants, on average, are less educated than nationals and EU migrants. 
Table 1 presents the percentage of EU and non-EU migrants who declare that they do not know the official language of the host country (or any official language in multilingual countries) either as mother tongue or as a foreign language (the AES provides data on respondents' language skills in up to seven foreign languages). We report results only if the sample at the level of the individual country contains at least 100 statistical observations, excluding nationals. Table 1 reveals that $5 \%$ of migrants living in the 17 countries examined do not know the official language of the host country. ${ }^{2}$ On average, lack of language skills is more likely among non-EU migrants (6\%) than among EU migrants (4\%). Large differences exist among countries in this respect. Table 1 presents results also for Switzerland. Although it is not an EU member state, it may be useful to consider it.

The AES contains data on the level of language proficiency in the first and second foreign languages spoken by respondents. Three proficiency levels are defined using "can do" descriptors. A fair level is defined as "I can understand and use the most common everyday expressions. I use the language in relation to familiar things and situations"; a good level is defined as "I can understand the essentials of clear language and produce simple text. I can describe experiences and events"; and a proficient level corresponds to "I can understand a wide range of demanding texts and use the language flexibly. I master the language almost completely”. In Austria, Germany, Greece, Italy, Luxemburg, Portugal and Switzerland at least two thirds $(66 \%)$ of migrants declare that they know at least one official language of the host country at a good or proficient level. In Belgium, Denmark, France, and Spain this percentage is at least 50\%, whereas in Cyprus, Estonia, Ireland, Latvia, Slovenia, and Sweden it lies below 50\%. EU migrants have better language skills in the official language of the host country than non-EU migrants, except for the Czech Republic and Switzerland.

\section{Language skills and employment status}

Good and very good language skills are associated with a better occupational status, both for EU and for non-EU migrants. We focus on respondents who participate in the labour market, that is, people with a job (either full-time or parttime) and the unemployed. In the 17 EU Member States examined, 87\% of EUmigrants declaring a good or proficient level of competence in the official lan-

2 Respondents declaring no knowledge of the local language were probably assisted during the interview. 
Table 1: Percentage of migrants who cannot use (at least one of) the official language(s) of the host country (17 EU member states and Switzerland)

\begin{tabular}{|c|c|c|c|c|c|c|}
\hline Country & $\begin{array}{l}\text { Official/dominant } \\
\text { language(s) }\end{array}$ & $\begin{array}{l}\text { EU mi- } \\
\text { grants }\end{array}$ & $\begin{array}{l}\text { Non-EU } \\
\text { migrants }\end{array}$ & $\begin{array}{l}\text { Tot mi- } \\
\text { grants }\end{array}$ & $\begin{array}{l}\text { Corresponding } \\
\text { population }\end{array}$ & $N$ \\
\hline Austria & German & $1 \%$ & $3 \%$ & $2 \%$ & 11,132 & (549) \\
\hline Belgium & $\begin{array}{l}\text { Dutch, French, Ger- } \\
\text { man }\end{array}$ & $7 \%$ & $16 \%$ & $10 \%$ & 64,458 & (432) \\
\hline Cyprus & Greek, Turkish & $19 \%$ & $26 \%$ & $22 \%$ & 20,811 & (516) \\
\hline Czech Rep. & Czech & $39 \%$ & $12 \%$ & $28 \%$ & 25,837 & (104) \\
\hline Denmark & Danish & $7 \%$ & $21 \%$ & $15 \%$ & 27,696 & (220) \\
\hline Estonia & Estonian & $48 \%$ & $60 \%$ & $60 \%$ & 68,892 & (544) \\
\hline France & French & $8 \%$ & $14 \%$ & $12 \%$ & 271,813 & (739) \\
\hline Germany & German & $2 \%$ & $2 \%$ & $2 \%$ & 98,565 & (316) \\
\hline Greece & Greek & $0 \%$ & $1 \%$ & $1 \%$ & 2,643 & (257) \\
\hline Ireland & Irish/English & $7 \%$ & $6 \%$ & $7 \%$ & 19,674 & $(1,329)$ \\
\hline Italy & Italian & $7 \%$ & $7 \%$ & $7 \%$ & 111,402 & (412) \\
\hline Latvia & Latvian & $22 \%$ & $21 \%$ & $22 \%$ & 6,352 & (119) \\
\hline Luxemburg & $\begin{array}{l}\text { Luxembourgish, } \\
\text { French, German }\end{array}$ & $1 \%$ & l & $1 \%$ & 354 & (441) \\
\hline Portugal & Portuguese & $2 \%$ & $2 \%$ & $2 \%$ & 4,597 & (376) \\
\hline Slovenia & Slovene & $17 \%$ & $14 \%$ & $14 \%$ & 6,658 & (126) \\
\hline Spain & Spanish & $0 \%$ & $0 \%$ & $0 \%$ & 8,847 & $(1,385)$ \\
\hline Sweden & Swedish & $13 \%$ & $30 \%$ & $22 \%$ & 75,425 & (249) \\
\hline \multicolumn{2}{|c|}{ Total population } & 262,347 & 562,809 & & 825,156 & $(8,114)$ \\
\hline \multicolumn{2}{|l|}{$\%$ migrants } & $4 \%$ & $6 \%$ & $5 \%$ & & \\
\hline Switzerland & $\begin{array}{l}\text { French, German, } \\
\text { Italian }\end{array}$ & $1 \%$ & $6 \%$ & $2 \%$ & 36,833 & $(3,478)$ \\
\hline
\end{tabular}

Source: Eurostat, AES (2013)

guage of the host country (or in at least one of its official languages) are employed; $13 \%$ are unemployed. By contrast, $78 \%$ of EU-migrants declaring no knowledge or only a fair level of knowledge of the official language have a job; $22 \%$ are unemployed.

Turning to non-EU migrants, $77 \%$ of respondents declaring good or very good skills in the official language of the host country are employed, whereas $23 \%$ are unemployed. These percentages are, respectively, $68 \%$ and $32 \%$, in the group of non-EU migrants declaring no knowledge of the local language or only a fair level of competence in it. Results do not change if we focus only on men.

These figures support the results of the studies quoted in the introduction: generally speaking, good and very good skills in the official language(s) of the 
host country are more frequent among those who have a better employment status, both for EU and non-EU migrants. ${ }^{3}$ Clearly, this link does not mean causal relationship because other variables play a role in explaining the employment status of migrants, for example education (which in turn is usually correlated to foreign language skills). In order to confirm these results, multivariate analysis is needed, but unfortunately the AES does not always contain enough observations at the individual country level to carry out such an analysis.

Let us note, in concluding, that $88 \%$ of EU citizens who live in their home country and who are active in the labour market are employed and $12 \%$ are unemployed. Therefore, the percentage of employed EU migrants with good or very good skills in the official language of the host country ( $87 \%)$ is very close to the percentage of nationals who have a job in their home country. This can be viewed as one sign of the effective functioning of the European Single Market and further evidence of the positive effect of good language skills on migrants' economic integration.

\section{References}

Adserà, Alícia \& Mariola Pytliková. 2016. Language and migration. In Victor Ginsburgh \& Shlomo Weber (eds.), The Palgrave handbook of economics and language, 342-72. Basingstoke: Palgrave.

Aparicio-Fenoll, Ainhoa \& Zoë Kuehn. 2016. Does foreign language proficiency foster migration of young individuals within the European Union? In Michele Gazzola \& Bengt-Arne Wickström (eds.), The economics of language policy, 331-56. Cambridge, MA: MIT Press.

Chiswick, Barry R. \& Paul W. Miller. 2014. International migration and the economics of language. In Barry R. Chiswick \& Paul W. Miller (eds.), Handbook of the economics of international migration. Amsterdam: North Holland.

European Commission. 2005. A New Framework Strategy for Multilingualism. Brussels: European Commission.

Gazzola, Michele, François Grin \& Bengt-Arne Wickström. 2016. A concise bibliography of language economics. In Michele Gazzola \& Bengt-Arne Wickström (eds.), The economics of language policy, 53-92. Cambridge, MA: MIT Press.

Grin, François, László Marác, Nike K. Pokorn \& Peter A Kraus. 2014. Mobility and inclusion in multilingual Europe: A position paper on the MIME project.

3 Some exceptions exist nevertheless, notably in Cyprus, Luxemburg, and in the Czech Republic for EU migrants, and in Austria, Denmark, France, and Portugal for non-EU migrants. In Switzerland, we do not observe significant differences in employment status between migrants who speak at least one of the official Swiss languages at a good or proficient level and migrants with limited or no linguistic competences. 
http://www.mime-project.org/resources/MIME-POSITION-PAPER-V4.pdf (accessed 14 July 2016).

Pulinx, Reinhilde, Piet Van Avermaet \& Claire Extramiana. 2014. Linguistic integration of adult migrants: Policy and practice. Strasburg: Council of Europe. https://rm.coe.int/CoERMPublicCommonSearchServices/DisplayDCTMContent? documentld=09000016802fc1ce (accessed 14 July 2016). 